\title{
What do Cells have to do with Forest Resource Statistics?
}

\author{
by
}

\author{
J. Monty ${ }^{1}$
}

\begin{abstract}
The availability of reliable, location-specific national resource statistics is of growing importance to strategic planners and policy makers. This paper describes the formation and use of "grid cells" for georeferencing summarized forest inventory data used to produce location-specific national forestry statistics.
\end{abstract}

Key words: Inventory, cells, geographic information system, data analysis.

\section{Résumé}

De plus en plus les planificateurs et les décideurs ont besoin de statistiques fiables et géographiquement détaillées sur les ressources nationales. L'auteur du présent rapport examine la formation et l'utilisation des "quadrilatères" pour la présentation des données des inventaires forestiers et la production de statistiques forstières nationales géographiquement détaillées.

Mots clés : Inventaire, quadrilatères, système d'information géographique, analyse de données.

\section{Introduction}

Because of growing concern about Canada's forest area and wood volume balance, government agencies have recognized the need to develop new strategies for forest management activities. To do this properly, resource managers and policy makers require an up-to-date national forest inventory and dynamic data on various aspects of the forest resource, such as depletion (harvest, alienations, burn, insects, and diseases), and forest accruals and improvements (growth, planting, spacing, fertilizing). This information must range from broad to detailed and be readily available, accurate, and location-specific. Therefore, they require a sophisticated storage and retrieval system. The development of Geographic Information Systems (GIS) has enabled these data requirements to be met.

Geographic Information Systems provide us with the capability of viewing, for the first time, a model of all the inventoried forest areas in Canada. Foresters can probe and analyze data relative to the forest type, volume, location and have maps produced. The data can form a basis for analytical models (e.g. wood supply).

Canada's Forest Inventory 1981 (Bonnor 1982) was the first national forest inventory publication in Canada to incorporate geo-referenced data. The upcoming 1986 national forest inventory will build upon the 1981 inventory.

TForest Research Officer, Petawawa National Forestry Institute, Chalk River, Ontario KOJ $1 \mathrm{JO}$

\section{Background}

Prior to the publication of Canada's Forest Inventory 1981 (Bonnor 1982), national forest inventories consisted of provincial data provided by resource agencies in response to questionnaires sent to them by the Canadian Forestry Service. The statistics produced were limited in scope and were not location-specific. Studies by Bonnor (1978 and 1979), and Moore and Bonnor (1980), determined that reliable forestry statistics for national overview could be geo-referenced using summary units called grid cells, and that a cell size of approximately $100 \mathrm{~km}^{2}$ would be suitable for reporting national forestry statistics. Each grid cell corresponds in area and location to a provincial forest inventory map sheet. Collectively, the cells make up a forestry grid covering most of the inventoried areas in Canada (Figure 1).

Each grid cell is referenced using a number that corresponds to the map index system used for provincial forest inventory map sheets. For example, the $10 \mathrm{~km}$ Universal Transverse Mercator (UTM) grid referencing system is used for the Prince Edward Island provincial base maps, while Meridian Township range is used in Alberta forest inventory maps. The $10 \mathrm{~km}$ UTM grid referencing system is preferred because it has an appropriate level of resolution for a national overview, covers all of Canada, and is easily understood and used (Moore and Bonnor 1980). The cell reference number is the coordinate of the southwest corner.

The referencing of forest resource information by grid cell allows a computer to conduct spatial analysis, and to retrieve and report on information anywhere within the inventoried forest area of Canada using GIS. This type of computer 


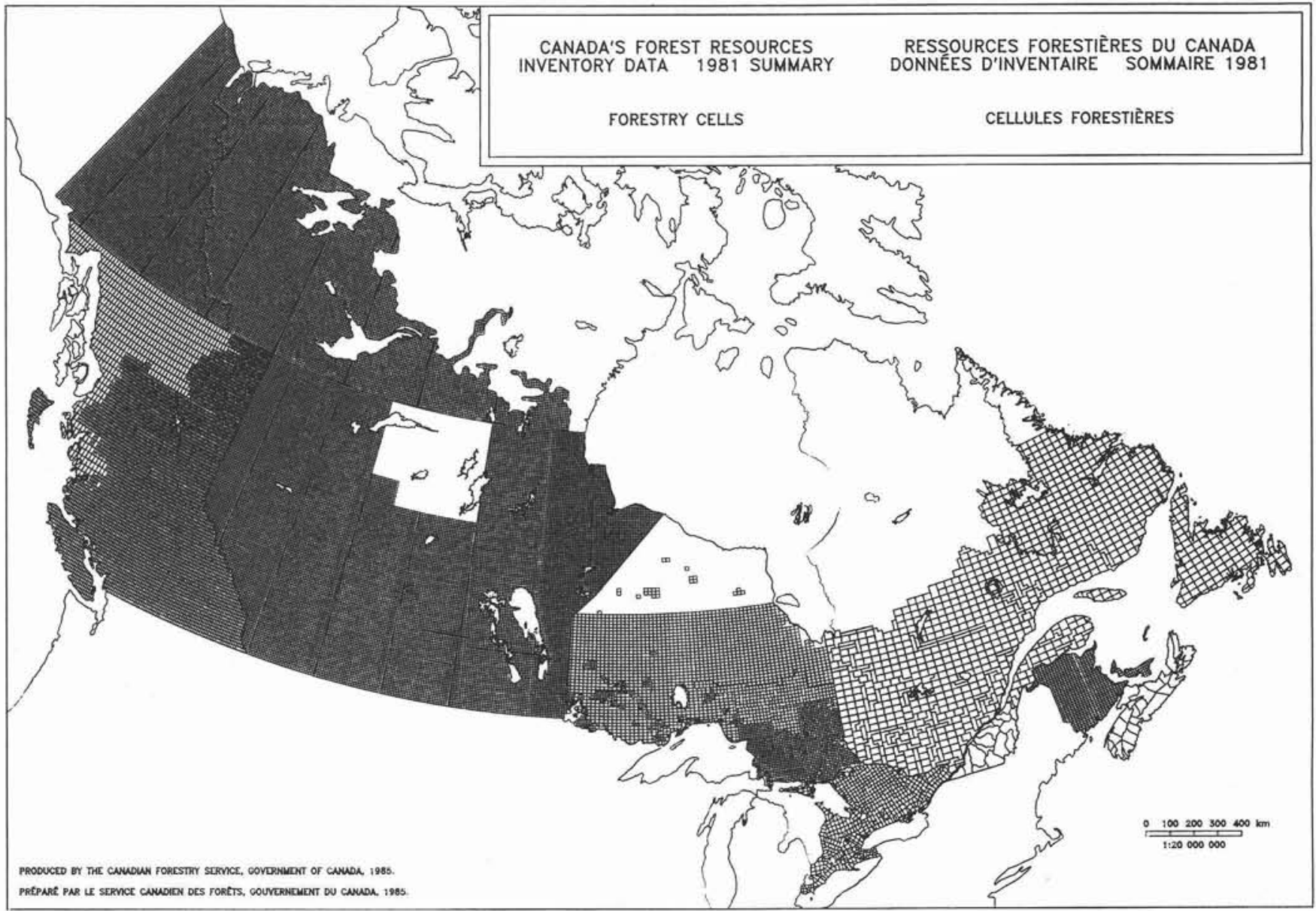

Figure 1. Canada's forestry cell grid.

application exists, and is known as the Canadian Forest Resource Data System (CFRDS). The CFRDS was designed by the Canadian Forestry Service to store, manipulate, and summarize national forest resource statistics.

\section{Grid Cell Data}

The grid cell, as a summary unit, contains descriptive information about the forest which is summarized and recoded. (For a more detailed description of cell data format, please refer to Appendix 1 of Bonnor 1982). Recoding is required because classification systems differ between provinces. Cell boundaries, usually the same as (neat line) boundaries of the provincial inventory map sheet, are digitized and stored. When requests for maps are made, the GIS provides capabilities to access these two files and then matches the digitized cell boundary with data selected for mapping

\section{Use of Grid Cell Data}

Although provincial agencies can usually retrieve forest stand-specific information by forest inventory map sheet ( \pm 1:20 000 scale), national overviews are typically limited to a scale of $\pm 1: 20000000$ because only summarized forest map sheet information is used. Any extra polation of information beyond this national resolution scale would impair the accuracy of data.
National overviews can be presented in tabular, graphic, or map form. The GIS can also conduct spatial analysis, and store and retrieve multiple forestry themes for mapping.

The maps are generally produced as choropleth maps (Figure 2) which indicate a particular theme. In deriving Figure 2 , the computer determines the available forested area of each grid cell and expresses it as a percentage of total cell area. Classes are created after a value has been calculated for each grid cell, and a colour or pattern is chosen for each class. In Figure 2 there are two classes, $0-50 \%$ and $51-100 \%$. Maps can also be produced to show overlays of information. For example, acid rain zones can be mapped over the productive forest land in Canada.

Currently, there are five databases available for analysis: forest inventory 1981 , biomass, access, acid precipitation and soil sensitivity, and Rowe's forest regions. There are a number of databases in progress: forest productivity, forest inventory 1986. Rowe's forest sections, forest structure (volume/ diameter relationships), policy constraints on timber harvest, and timber cull factors.

Forestry grid cells provide a mechanism for referencing national forest resource statistics. The cells are the framework within which to analyze and display Canada's national forest inventory.

For further information, please contact the Manager, Forest Inventory Program Group, Petawawa National Forestry Institute, Chalk River, Ont., KOJ 1JO (613) 589-2880. 


\section{FOREST LAND IN CANADA \\ Available for Timber Harvest}
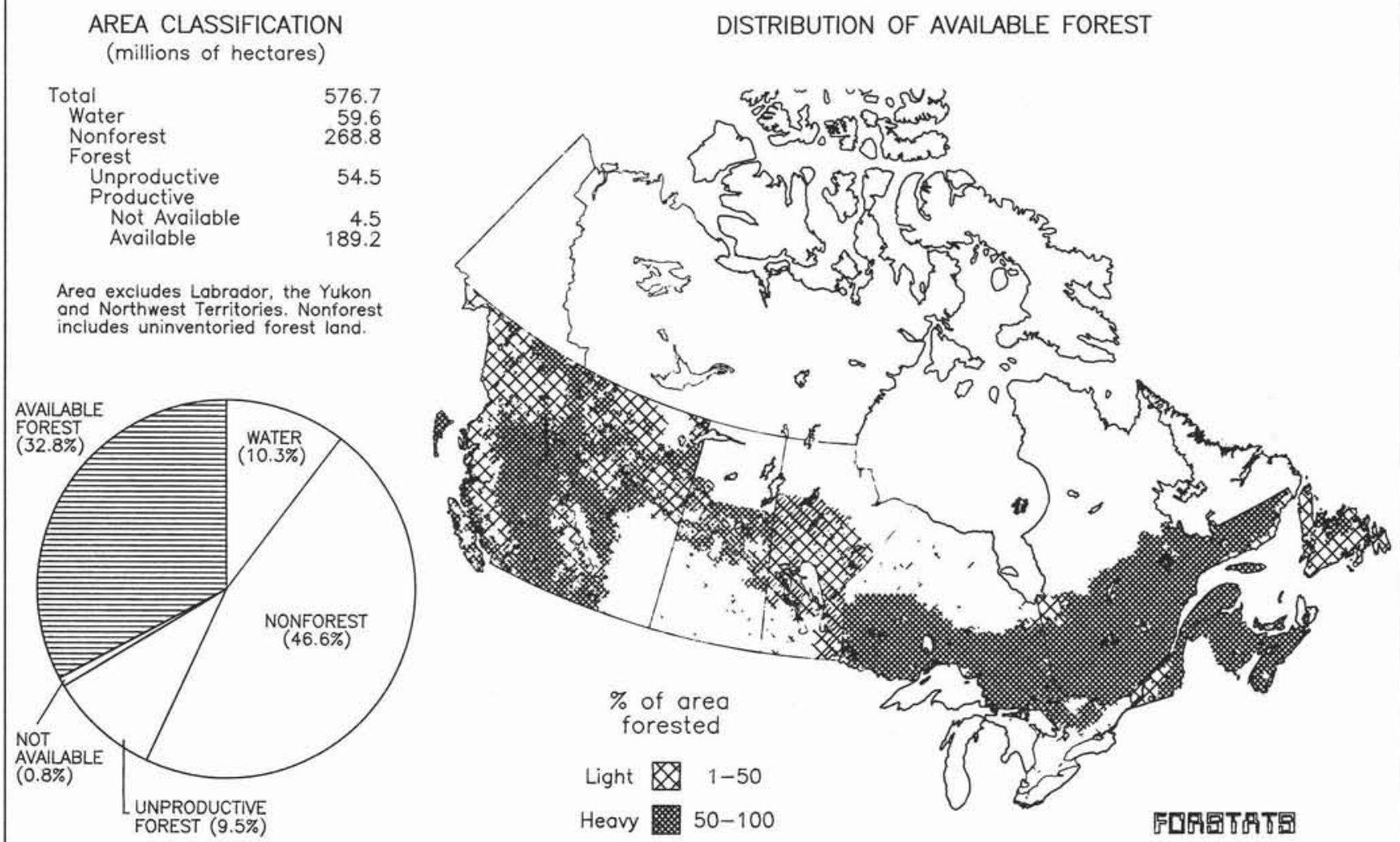

Source: Canada's Forest Inventory, 1981 (Bonnor, 1982), Canadian Forestry Service; Canoda Year Book (1980-1981), Statistics Canada Produced for the Canadian Forest Industries Council by the Petawowa National Forestry Institute, Canadian Forestry Service, 1986.

Figure 2. A choropleth map and associated products.

\section{References}

Bonnor, G.M. 1978. Pilot study for Canadian Forest Resource Data System. Forest Man. Inst., Inf. Rep. FMR-X-122.

Bonnor, G.M. 1979. National forestry statistics in Canada. Proc. Soc. Am. For./Can. Inst. For., Joint Conven., Oct. 1978, St. Louis, Mo.

Bonnor, G.M. 1982. Canada's forest inventory 1981. FORSTATS Can. For. Serv.

Moore, W.C. and G.M. Bonnor. 1980. Geographic referencing of national forestry data. For. Chron. 56: 6-10.

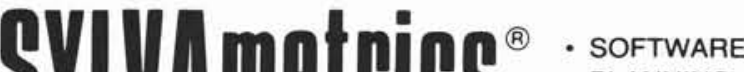 \\ - PLANNING \\ - appraisal} CONSULTING

David W. Ormerod, M.F., R.P.F

4672 Cordova Bay Road

Victoria, B.C., Canada V8X 3V7

(604) 658-8129 